\title{
Determinasi Karakteristik Keuangan Terhadap Nilai Perusahaan Dengan Moderasi Financial Literacy Pada Perusahaan LQ45 Di BEI
}

\author{
Dona Validanurhidayati ${ }^{1}$, Syahril Djaddang ${ }^{2}$, JMV. Mulyadi ${ }^{3}$ \\ ${ }^{1}$ Magister Akuntansi Pascasarjana Universitas Pancasila \\ ${ }^{23}$ Dosen Tetap Universitas Pancasila \\ Email : dona.validanurhidayati@gmail.com
}

Firm Value, Capital Structure and Profitability

Submitted: JANUARI 2021

Accepted: JULI 2021

\begin{abstract}
Many previous studies on the value of the company with the factors that affect the value of the company. From existing research, there are different research results. To test and analyze the effect of capital structure on firm value. The aims of this study are (1) to examine and analyze the effect of capital structure on firm value moderated by financial literacy. (2) To test and analyze the effect of dividend policy on firm value. (3) To examine and analyze the effect of dividend policy on firm value moderated by financial literacy. (4) To test and analyze the effect of profitability on firm value. And (5) To test and analyze the effect of profitability on firm value moderated by financial literacy. The type of data used in this study is secondary data from companies listed in LQ45. The data used is the annual financial report data for the period 2012 - 2016. The data sources used are obtained through the Indonesia Capital Market Directory (ICMD) and from internet searches at http://www.idx.co.id. The population in this study were all companies registered in LQ45 in 2012 - 2016. The sampling method in this study used a non-random sampling system (non-probability sampling) using purposive sampling. In this study, the researcher used judgment sampling because the sample to be used in this study had to meet several criteria. Data were analyzed using regression analysis. The results of this study indicate that capital structure has an effect on firm value, dividend policy has no effect on firm value, profitability has a significant effect on firm value, but financial literacy is not proven to moderate the effect of profitability on firm value.
\end{abstract}

Keywords: Firm Value, Capital Structure, Profitability, and Financial literacy

\section{ABSTRAK}

Banyak penelitian sebelumnya tentang nilai perusabaan dengan faktor faktor yang mempengaruhi nilai perusahaan. Dari penelitian yang sudah ada, terdapat basil penelitian yang berbeda-beda. Untuk menguji dan menganalisis pengaruh struktur modal terhadap nilai perusahaan. Tujuan penelitian ini adalah (1) Untuk menguji dan menganalisis pengaruh struktur modal terhadap nilai perusahaan yang dimoderasi oleh financial literacy. (2) Untuk menguji dan menganalisis pengaruh kebijakan dividen terhadap nilai perusahaan. (3) Untuk menguji dan menganalisis pengaruh kebijakan dividen terhadap nilai perusahaan yang dimoderasi oleh financial literacy. (4) Untuk menguji dan menganalisis pengaruh profitabilitas terhadap nilai perusahaan. Dan (5) Untuk menguji dan menganalisis pengaruh profitabilitas terhadap nilai perusahaan yang dimoderasi oleh financial literacy. Jenis data yang digunakan dalam penelitian ini adalah data sekunder dari perusahaan yang terdaftar di LQ45. Data yang digunakan adalah data laporan keuangan tahunan untuk periode 2012 - 2016. Sumber data yang digunakan ini diperoleh melalui Indonesia Capital Market Directory (ICMD) dan dari penelusuran internet di http//www.idx.co.id. Populasi dalam penelitian ini adalah seluruh perusahaan yang terdaftar di LQ45 tahun 2012 - 2016. Metode pengambilan sampel dalam

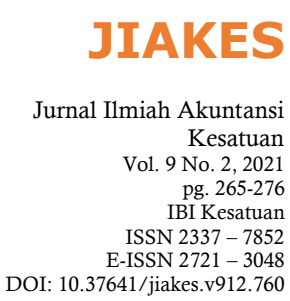


Firm Value, Capital Structure and Profitability penelitian ini menggunakan sistem non random sampling (nonprobability sampling) yaitu menggunakan purposive sampling. Dalam penelitian ini, peneliti menggunakan judgement sampling dikarenakan sampel yang akan digunakan dalam penelitian ini harus memenuhi beberapa kriteria. Data dianalisis menggunaka analisis regresi. Hasil dari penelitian ini menunjukkan bahwa struktur modal berpengaruh terhadap nilai perusahaan, kebijakan dividen tidak berpengaruh terhadap nilai perusahaan, Profitabilitas berpengaruh signifikan terhadap nilai pemsahaan tetapi financial literacy tidak terbukti memoderasi pengaruh profitabilitas terhadap nilai perusahaan.

Kata Kunci : nilai perusahaan, struktur modal, kemampulabaan, dan literasi keuangan

\section{PENDAHULUAN}

Indonesia menjadi salah satu negara tujuan untuk berinvestasi karena luas dan letak geografisnya. Banyaknya perusahaan baru dan kondisi perekonomian yang tidak menentu menciptakan persaingan ketat antar perusahaan di Indonesia. Persaingan ketat ini memaksa setiap perusahaan manufaktur meningkatkan kinerja perusahaan agar tujuan perusahaan dapat tetap tercapai. Salah satu tujuan perusahaan yaitu memaksimumkan kemakmuran pemegang saham melalui nilai perusahaan yang maksimal (Sartono, 2010: 8). Menurut Oka (2011), nilai perusahaan merupakan nilai pasar dari suatu ekuitas perusahaan ditambah nilai pasar hutang. Nilai perusahaan tercermin dari harga saham perusahaan, semakin tinggi harga saham perusahaan maka semakin tinggi pula nilai perusahaan (Sudana, 2009: 7).

Selain harga saham perusahaan, nilai perusahaan lazim diindikasikan dengan Price to Book Value (PBV). Nilai buku merupakan nilai saham menurut pembukuan emiten, nilai pasar merupakan pembukuan nilai saham di pasar saham, dan nilai intrinsik merupakan nilai sebenamya dari saham. Salah satu pendekatan dalam menentukan nilai intrinsik saham adalah price to book value. Prace to book value merupakan salah satu rasio penilaian yaitu rasio yang memberikan ukuran kemampuan manajemen menciptakan nilai pasar usahanya diatas biaya investasi dengan cara membandingkan nilai pasar saham terhadap nilai buku (Kasmir, 2009: 116). Semakin tinggi rasio PBV dapat diartikan semakin berhasil perusahaan menciptakan nilai bagi pemegang saham yang berdampak pada nilai perusahaan. Price to book value yang tinggi akan membuat pasar percaya akan prospek perusahaan ke depan. Berikut ini data PBV perusahaan LQ45 periode 2012 sampai 2016

Tabel 1. Nilai Perusahaan LQ45 Tahun 2012 - 2016 (X)

\begin{tabular}{lccccc}
\hline \multicolumn{1}{c}{ Nama Perusahaan } & 2012 & 2013 & 2014 & 2015 & 2016 \\
\hline Astra Agro Lestari Tbk & 4.06 & 3.31 & 3.85 & 3.41 & 2.13 \\
ADHI KARYA (Persero) Tbk & 1.05 & 2.68 & 1.76 & 4.10 & 1.48 \\
Adaro Energy Tbk & 2.56 & 1.76 & 0.89 & 0.81 & 0.36 \\
AKR Corporindo Tbk & 3.23 & 3.80 & 3.17 & 2.84 & 3.89 \\
Astra lnternasional Tbk & 3.95 & 3.43 & 2.59 & 2.60 & 1.92 \\
Alam Sutera Realty Tbk & 2.95 & 2.49 & 1.58 & 1.81 & 1.02 \\
Global Mediacom Tbk & 4.69 & 4.32 & 3.70 & 4.33 & 3.66 \\
Bumi Serpong Damai Tbk & 2.08 & 1.84 & 1.68 & 1.89 & 1.57 \\
Charoen Pokphand indonesia Tbk & 5.70 & 7.32 & 5.56 & 5.68 & 3.39 \\
Gudang Garam Tbk & 4.86 & 4.07 & 2.75 & 3.66 & 2.78 \\
\hline
\end{tabular}

Sumber: IDX LQ45 2017 
Berdasarkan tabel 1, dapat dilihat pada tahun 2012 sebagian besar perusahaan LQ45 mengalami penurunan. Tahun 2015 semua perusahaan LQ45 kecuali AKR Corporindo Tok. mengalami penurunan kembali. Astra, Andaro, Alam Sutera, Bumi Serpong, dan Gudang Garam Tok. mengalami penurunan nilai perusahaan yang diproksikan oleh PBV di tahun 2012, 2013, 2014, dan 2015. Adhi Karya, AKR Corporindo, dan Charoen Pokphand Indonesia mulai mengalami penurunan di tahun 2013, mengalami peningkatan di tahun 2014 dan kembali menurun di tahun 2015. PT. Astra Agro Lestari Tok. mengalami penurunan nilai perusahaan di tahun 2012, terdapat kenaikan nilai di tahun 2013 dan mengalami penurunan kembali di tahun 2014 sampai 2015. PT. Adhi Karya Tbk. mengalami kenaikan nilai dari angka 1,76 menjadi 4,10 di tahun 2014 dan kembali di angka 1,48 di tahun 2015. Berikut data garafik yang menunjukkan rata-rata nilai perusahaan LQ45 dari tahun 2021 sampai dengan tahun 2016.

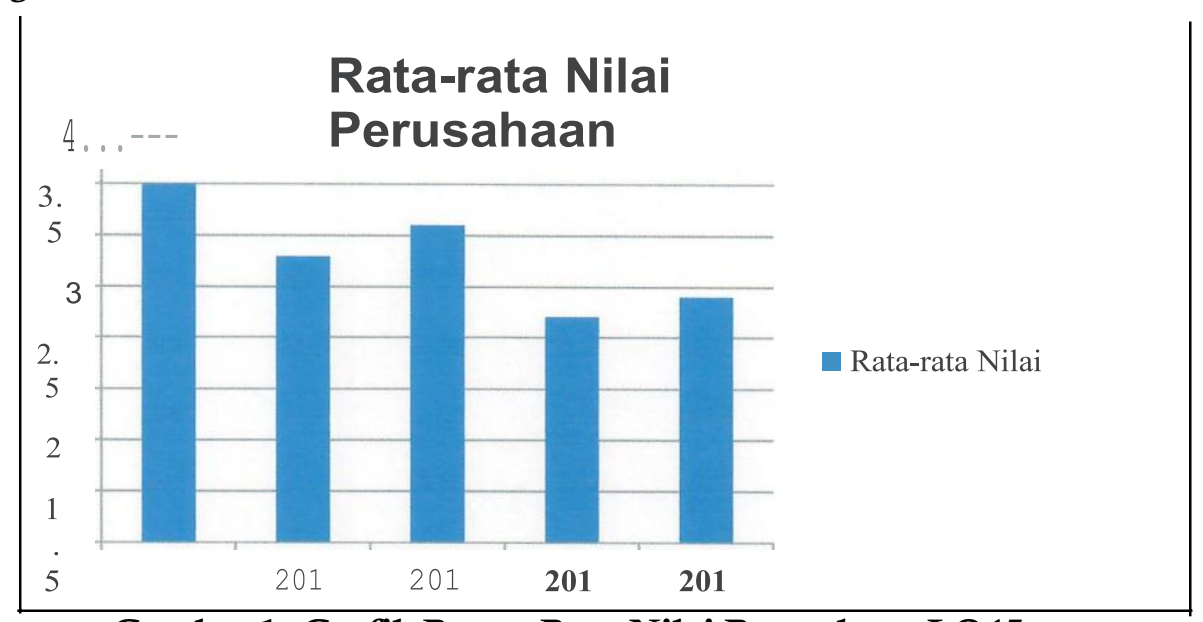

Gambar 1. Grafik Rata - Rata Nilai Perusahaan LQ45

Sumber: IDX LQ45 2017

Data tersebut menunjukkan bahwa rata-rata nilai perusahaan berdasarkan price to book value perusahaan yang terdaftar di LQ45 periode 2012 sampai 2016 mengalami fluktuasi (naik turun). Dari data tersebut menunjukkan bahwa rata-rata nilai perusahaan mengalami penurunan di tahun 2013 dan tahun 2015. Terdapat banyak faktor yang dapat mempengaruhi nilai perusahaan, diantaranya yaitu struktur modal, kebijakan dividen, dan profitabilitas. Melaksanakan fungsi manajemen keuangan dengan tepat mengenai setiap keputusan keuangan yang diambil akan berdampak terhadap nilai perusahaan. Keputusan keuangan yang harus dipertimbangkan adalah keputusan pendanaan dan kebijakan dividen. Keputusan pendanaan berkaitan dengan penentuan struktur modal yang tepat bagi perusahaan dan kebijakan hutang yang diambil perusahaan. Kebijakan dividen berkaitan dengan seberapa besar laba yang diperoleh perusahaan akan didistribusikan kepada pemegang saham. Profitabilitas merupakan kemampuan perusahaan menghasilkan laba dari modal yang dimiliki perusahaan.

Struktur modal merupakan perpaduan sumber dana jangka panjang (long- term sources of funds) yang digunakan perusahaan. Target dari struktur modal adalah menciptakan suatu komposisi hutang dan modal sendiri yang paling tepat bagi perusahaan. Rasio yang umum digunakan untuk melihat pengaruh pinjaman dari kreditor adalah rasio hutang yang dilihat dari struktur modal yaitu Debt to Equity Ratio (DER). Kebijakan dividen terkait penentuan seberapa besar laba perusahaan akan dibagikan sebagai dividen, maka rasio pembayaran dividen atau dividend payout ratio (DPR) dapat menggambarkan kebijakan dividen. Kemampuan perusahaan menciptakan laba yang disebut profitabilitas dapat dilihat dari pengelolaan modal perusahaan dengan maksimal. Return On Assets (ROA) mencerminkan basil pengelolaan modal perusahaan yang dimiliki.

\author{
Firm Value, \\ Capital Structure \\ and Profitability
}


Firm Value, Capital Structure and Profitability

268
Pada era globalisasi sekarang ini sangat dibutuhkan dan diperlukan pengetahuan tentang pengelolaan keuangan dengan baik dan cermat. Di Indonesia, tingkat pengetahuan keuangan atau financial knowledge dari masyarakat Indonesia dapat dikatakan masih jauh tertinggal dari Malaysia, Singapura, Filipina, dan Thailand (Jannah, 2014) dalam Budiono (2014). Maka dari itu untuk dapat memiliki daya saing yang kuat dengan masyarakat luar dibutuhkanlah pengetahuan tentang literasi keuangan. Literasi keuangan menurut Otoritas Jasa Keuangan (2013, h.24) adalah rangkaian proses atau aktifitas untuk meningkatkan pengetahuan (knowledge), keyakinan (confidence) dan keterampilan (skill) konsumen dan masyarakat luas sehingga mereka mampu mengelolah keuangan dengan lebih baik. Literasi keuangan merupakan kemampuan seorang individu untuk mengambil keputusan dan mengelolah dana yang dimiliki secara bijak, yang diawali dengan mengetahui, memahami, meyakini, hingga menjadi terampil untuk terlibat aktif dalam mengatur keuangan demi sejabtera dimasa yang akan datang.

Banyak penelitian sebelumnya tentang nilai perusabaan dengan faktor- faktor yang mempengarubi nilai perusahaan. Dari penelitian yang sudah ada, terdapat basil penelitian yang berbeda-beda. Penelitian Dewi dan Wirajaya (2013), menunjukkan bahwa struktur modal berpengarub negatif dan profitabilitas berpengaruh positif pada nilai perusabaan. Penelitian yang dilakukan oleh Sofyaningsih (2011), menunjukkan bahwa kebijakan dividen tidak mempengaruhi nilai perusabaan. Penelitian Ahmad dan Putri (2012), menunjukkan babwa kebijakan dividen dan profitabilitas berpengaruh positif terhadap nilai perusahaan. Penelitian yang dilakukan oleb Prasetyorini (2013), menunjukkan babwa kebijakan dividen dan profitabilitas berpengarub pada nilai perusahaan. Penelitian yang dilakukan oleb Ta'dir dkk (2014) menunjukkan basil bahwa struktur modal berpengaruh tidak signifikan terhadap nilai perusabaan. Penelitian Umi dkk (2012) menunjukkan kebijakan dividen berpengaruh tidak signifikan dan profitabilitas berpengaruh positif terbadap nilai perusabaan. Gayatri dan Mustanda (2014) menyatakan struktur modal berpengaruh positif terhadap nilai perusahaan dalam penelitian yang telab dilakukan. Dan penelitian yang dilakukan oleb Hikmab Endraswati (2010) menunjukkan basil kebijakan dividen berpengarub signifikan positif terbadap nilai perusahaan.

Tujuan penelitian ini adalah sebagai berikut: (1) Untuk menguji dan menganalisis pengaruh struktur modal terhadap nilai perusahaan. (2) Untuk menguji dan menganalisis pengaruh struktur modal terhadap nilai perusahaan yang dimoderasi oleh financial literacy. (3) Untuk menguji dan menganalisis pengaruh kebijakan dividen terhadap nilai perusahaan. (4) Untuk menguji dan menganalisis pengaruh kebijakan dividen terhadap nilai perusahaan yang dimoderasi oleh financial literacy. (5) Untuk menguji dan menganalisis pengaruh profitabilitas terhadap nilai perusahaan. (6) Untuk menguji dan menganalisis pengaruh profitabilitas terhadap nilai perusahaan yang dimoderasi oleh financial literacy.

\section{Kerangka Pemikiran}

Salah satu tujuan perusahaan yaitu memaksimumkan kemakmuran pemegang saham melalui nilai perusahaan yang maksimal (Sartono, 2010: 8). Menurut Oka (2011), nilai perusahaan merupakan nilai pasar dari suatu ekuitas perusahaan ditambah nilai pasar hutang. Nilai perusahaan lazim diindikasikan dengan Price to Book Value (PBV). Nilai buku merupakan nilai saham menurut pembukuan emiten, nilai pasar merupakan pembukuan nilai saham di pasar saham, dan nilai intrinsik merupakan nilai sebenarnya dari saham. Salah satu pendekatan dalam menentukan nilai intrinsik saham adalah price to book value. Banyak faktor yang mempengaruhi nilai perusahaan, diantaranya adalah struktur modal, kebijakan dividen, dan profitabilitas.

Struktur modal merupakan perpaduan sumber dana jangka panjang (long- term sources of funds) yang digunakan perusahaan. Target dari struktur modal adalah menciptakan suatu komposisi hutang dan modal sendiri yang paling tepat bagi perusahaan. Rasio yang umum 
digunakan untuk melihat pengaruh pinjaman dari kreditor adalah rasio hutang yang dilihat dari struktur modal yaitu Debt to Equity Ratio (DER). Kebijakan dividen terkait penentuan seberapa besar laba perusahaan akan dibagikan sebagai dividen, maka rasio pembayaran dividen atau dividend payout ratio (DPR) dapat menggambarkan kebijakan dividen. Kemampuan perusahaan menciptakan laba yang disebut profitabilitas dapat dilihat dari pengelolaan modal perusahaan dengan maksimal. Return On Assets (ROA) mencerminkan basil pengelolaan asset perusahaan yang dimiliki. Literasi keuangan merupakan kemampuan seorang individu untuk mengambil keputusan dan mengelolah dana yang dimiliki secara bijak, yang diawali dengan mengetahui, memahami, meyakini, hingga menjadi terampil untuk terlibat aktif dalam mengatur keuangan demi sejahtera dimasa yang akan datang.

Penelitian Dewi dan Wirajaya (2013), menunjukkan bahwa struktur modal berpengaruh negatif dan profitabilitas berpengaruh positif pada nilai perusahaan. Penelitian yang dilakukan oleh Sofyaningsih (2011), menunjukkan bahwa kebijakan dividen tidak mempengaruhi nilai perusahaan. Penelitian Ahmad dan Putri (2012), menunjukkan bahwa kebijakan dividen dan profitabilitas berpengaruh positif terhadap nilai perusahaan. Penelitian yang dilakukan oleh Prasetyorini (2013), menunjukkan bahwa kebijakan dividen dan profitabilitas berpengaruh pada nilai perusahaan. Penelitian yang dilakukan oleh Ta'dir dkk (2014) menunjukkan basil bahwa struktur modal berpengaruh tidak signifikan terhadap nilai perusahaan. Penelitian Umi dkk (2012) menunjukkan kebijakan dividen berpengaruh tidak signifikan dan profitabilitas berpengaruh positif terhadap nilai perusahaan. Gayatri dan Mustanda (2014) menyatakan struktur modal berpengaruh positif terhadap nilai perusahaan dalam penelitian yang telah dilakukan. Dan penelitian yang dilakukan oleh Hikmah Endraswati (2010) menunjukkan basil kebijakan dividen berpengaruh signifikan positif terhadap nilai perusahaan.

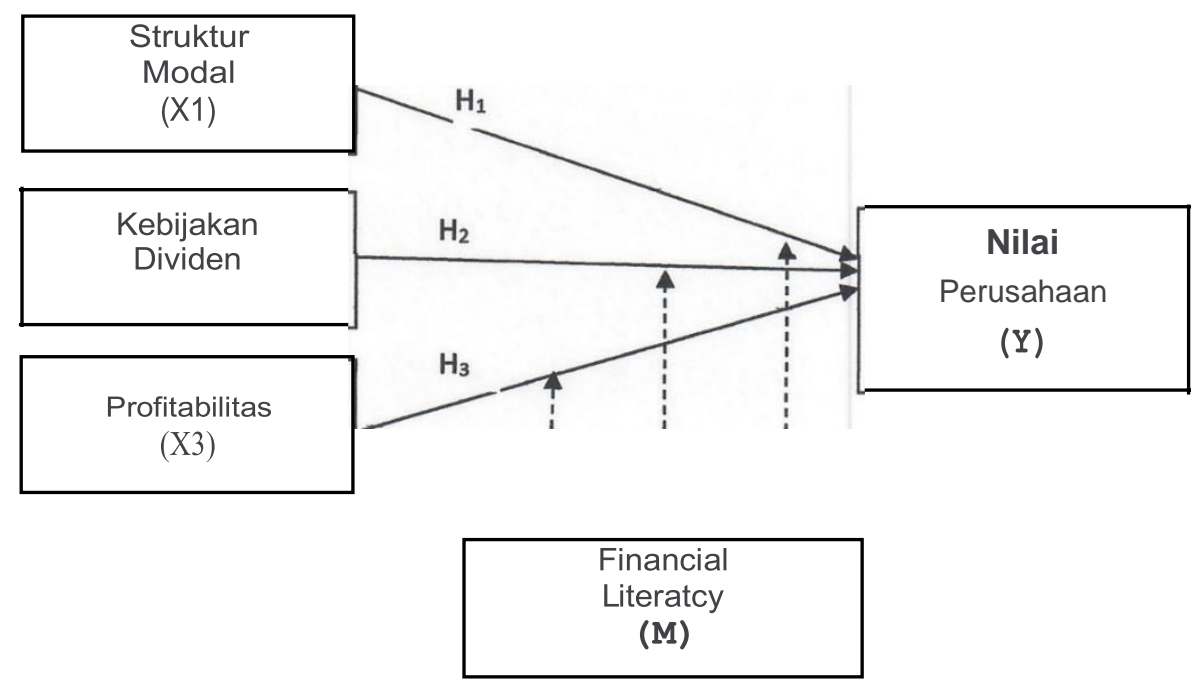

Gambar 2. Model Penelitian

Berdasarkan kerangka pemikiran dalam penelitian ini dapat didefinisikan bahwa variabel independen terdiri dari struktur modal (XI), kebijakan dividen $\{\mathrm{X} 2$ ), profitabilitas (X3) dan variabel dependennya ialah nilai perusahaan $(\mathrm{Y})$ serta memasukan variable moderasi yaitu financial literacy (M).

\section{METODE PENELITIAN}

Jenis dan Sumber Data. Jenis data yang digunakan dalam penelitian ini adalah data sekunder dari perusahaan yang terdaftar di LQ45. Data yang digunakan adalah data laporan keuangan tahunan untuk periode 2012 - 2016. Sumber data yang digunakan ini diperoleh

\author{
Firm Value, \\ Capital Structure \\ and Profitability
}

269 
Firm Value, Capital Structure and Profitability melalui Indonesia Capital Market Directory (ICMD) dan dari penelusuran internet di http//www.idx.co.id. adapun data berupa laporan keuangan yang terdiri dari :

1. Data laporan posisi keuangan perusahaan LQ45 tanggal 31 Desember periode 2012 2016.

2. Data Laporan laba rugi perusahaan LQ45 tanggal 31 Desember periode 2012 - 2016.

3. Data laporan arus kas perusahaan LQ45 tanggal 31 Desember 2012- 2016.

Populasi dalam penelitian ini adalah seluruh perusahaan yang terdaftar di LQ45 tahun 2012 - 2016. Metode pengambilan sampel dalam penelitian ini menggunakan sistem non random sampling (nonprobability sampling) yaitu menggunakan purposive sampling, melalui proses judgement sampling dikarenakan sampel yang akan digunakan dalam penelitian ini harus memenuhi beberapa kriteria berikut:

1. Perusahaan yang terdaftar di LQ45 pada tahun 20012 sampai dengan 31 Desember 2016.

2. Perusahaan yang mempunyai laporan keuangan lengkap sesuai dengan yang diperlukan dalam variabel penelitian tahun 2012-2016.

3. Perusahaan yang tidak melakukan transaksi merger atau akuisisi minimal sekali selama periode 31 Desember 2012 - 31 Desember 2016, melakukan restrukturisasi, dan mengalami perubahan kelompok usaha.

Pengumpulan data dilakukan dengan teknik dokumentasi, dikumpulkan, diseleksi, dan kemudian diolah. Variabel yang digunakan dalam penelitian ini adalah variabel dependen yang berupa nilai perusahaan. Sedangkan variabel independennya adalah struktur modal, kebijakan dividen, dan profitabilitas. Dalam penelitian ini terdapat variabel moderasi yaitu financial literacy. Data dianalisis dengan metode Analisis Deskriptif. Untuk mengukur kualitas data dilakukan uji asumsi klasik. Uji hipotesis dilakukan dengan menggunakan Moderated Regression Analysis (MRA).

HASIL DAN PEMBAHASAN

Analisis Deskriptif

Tabel 4. Statistik Deskriptif Perusahaan LQ45 Periode 2012-2016

\begin{tabular}{lcccccc|}
\hline & Variabel & $\mathrm{N}$ & Minimum & Maximum & Mean & Std. Deviation \\
\hline PBV & 56 &, 36 & 58,48 & 6,1261 & 12,25178 \\
DER & 56 &, 16 & 2,26 &, 7836 &, 53503 \\
DPR & 56 & 4,09 & 99,96 & 46,9302 & 20,93234 \\
ROA & 56 & 2,53 & 71,51 & 13,6700 & 11,40648 \\
FL & 56 & 8,87 & 28,68 & 16,8148 & 5,32782 \\
DER*FL & 56 & 2,32 & 36,91 & 12,5264 & 8,60572 \\
DPR*FL & 56 & 111,10 & 1838,96 & 761,3714 & 383,98995 \\
ROA*FL & 56 & 29,08 & 996,63 & 229,1430 & 179,94243 \\
Valid N (listwise) & 56 & & & & \\
\hline
\end{tabular}

Sumber: Data Bursa Efek Indonesia yang diolah

Berdasarkan hasil analisis deskriptif menunjukkan bahwa nilai perusahaan yang diproksi oleh PBV memiliki nilai minimum 0,36; nilai maksimum 58,48; nilai mean sebesar 6,13 dan standar deviasi sebesar 12,25. Jumlah data yang dignnakan dalam penelitian ini sebanyak 56. Struktur modal (DER) memiliki nilai minimum 0,16; nilai maksimum 2,26; nilai mean sebesar 0,78 dan standar deviasi sebesar 0,54. Kebijakan dividen (DPR) memiliki nilai minimum 4,09; nilai maksimum 99,96; nilai mean sebesar 46,93; dan standar deviasi sebesar 20,93. Dijelaskan Profitabilitas (ROA) memiliki nilai minimum 2,53; nilai maksimum 71,51; nilai mean sebesar 13,67; dan standar deviasi sebesar 11,41.

Hasil Uji Kualitas Data

Untuk memperoleh basil pengujian yang baik, maka semua data yang dibutuhkan dalam penelitian ini harus diuji terlebih dahulu agar tidak melanggar asumsi klasik yang 
disyaratkan. Hal ini bertujuan agar hasil pengujian hipotesis yang dilakukan dapat dipertanggungjawabkan kebenarannya, pengujian asumsi klasik yang dilakukan pada penelitian ini meliputi uji normalitas, uji multikolinearitas, uji heteroskedastisitas, dan uji autokorelasi. Berdasarkan pengolahan, data yang digunakan berdistribusi normal menggunakan normaliti Q - Q plot yang memperlihatkan bahwa data berdistribusi normal dimana titik-titik nya berada di area grafik. Dari hasil uji statistik di atas dapat disimpulkan bahwa data berdistribusi normal dengan sig. <0,05. Dimana DER dengan sig. 0,016; DPR dan $\mathrm{DPR}^{*} \mathrm{FL}$ dengan sig. 0,001; dan ROA, FL, PBV, DER*FL, dan ROA*FL dengan sig. 0,000 .

Dari hasil pengujian multikolinearitas diketahui bahwa nilai tolerance untuk variabel struktur modal (DER), kebijakan dividen (DPR), profitabilitas (ROA), dan variabel moderasifinancial literacy lebih dari 0,10 dan VIF kurang dari 10. Oleh karena itu dapat disimpulkan bahwa variabel independen-variabel independen struktur modal (DER) , kebijakan dividen (DPR), profitabilitas (ROA), dan financial lieracy tidak memiliki masalah multikolinearitas antar variabel independen tersebut. Dari hasil uji correlations antara variabel independen struktur modal (DER), kebijakan dividen (DPR), profitabilitas (ROA), dan financial literacy dengan unstandarized Residual menghasilkan nilai signifikansi (Sig 2tailed) masing-masing sebesar 1,000. Kesimpulan yang dapat ditarik berdasarkan hasil tersebut adalah nilai signifikansi korelasi lebih besar dari 0,05 sehingga dapat dinyatakan model regresi tidak ditemukan adanya masalah heteroskedastisitas. Uji autokorelasi menunjukkan nilai DW (durbin- watson) yang dihasilkan dari model regresi adalah sebesar 1,734. Sedangkan dari tabel DW dengan signifikansi 0,05 , jumlah data (n) sebanyak 56 , dan jumlah variabel independen $(\mathrm{k}) 4$ diperoleh nilai $\mathrm{d} 1=1,4201 \mathrm{dan} \mathrm{du}=1,7246$. Nilai $\mathrm{DW}$ berada di antara d1 dan 4-du atau 1,4201<1,734<4-1,7246 sehingga dapat disimpulkan model regresi ini tidak ada problem autokorelas.i

\section{Hasil Uji Hipotesis}

Penelitian ini bertujuan untuk melihat bagaimana struktur modal, kebijakan dividen, dan profitabilitas menjelaskan nilai perusahaan. Untuk membuktikan hal tersebut, terdapat beberapa hipotesis yang dikembangkan. Hipotesis dalam penelitian ini terdiri dari enam hipotesis yang diuji dengan menggunakan regresi linear berganda, dan untuk varibel financial literacy digunakan Moderating Regression Analysis (MRA) dalam pengujian hipotesisnya terhadap nilai pemsahaan, karena adanya variabel moderasi yaitu financial literacy dalam menjelaskan nilai perusahaan.

Tabel 5. Uji Kelayakan Model Perusahaan LQ45 Periode 2012 - 2016

\begin{tabular}{llrrrrr}
\hline Model & & Sum of Squares & Df & Mean Square & F & Sig. \\
1 & Regression & 7139,576 & 7 & 1019,939 & 43,858 &, $000^{b}$ \\
& Residual & 1116,267 & $\mathbf{4 8}$ & 23,256 & & \\
& Total & 8255,843 & 55 & & & \\
\hline
\end{tabular}

a. Dependent Variable: PBV

b. Predictors: (Constant), ROA*FL, DER, DPR*FL, FL, DPR, DER*FL, ROA

Sebelum pembahasan hipotesis menggunakan MRA, model harus dilakukan uji kelayakan model. Uji ini bertujuan memastikan model regresi yang digunakan layak untuk melakukan uji hipotesis. Berdasarkan uji kelayak:an model, tabel 4.5 menunjukkan bahwa model regresi ini layak digunakan untuk dilak:ukan penelitian dengan nilai signifikansi 0,000 dimana sig. $<5 \%$.

Berdasarkan uji hipotesis (uji t) didapatkan basil bahwa variabel struktur modal (DER), profitabilitas (ROA), dan struktur modal yang dimoderasijinancial literacy (DER*FL) terbukti mempengaruhi nilai perusallaan (PBV) dengan nilai signifikansi $<5 \%$.

Berdasarkan hasil uji t dapat disimpulkan sebagai berikut :

1. $\mathrm{H}_{1}$ menyatakan bahwa struktur modal berpengaruh signifikan terhadap nilai pemsahaan.
Firm Value, Capital Structure and Profitability

271 
Firm Value, Capital Structure and Profitability

272
Berdasarkan basil statistik menunjukkan signifikansi 0,001 yang artinya stmktur modal berpengamh signifikan terhadap nilai pemsahaan.

$\mathrm{H}_{1 \mathrm{a}}$ menyatakan bahwa struktur modal yang dimoderasi olehjinancial literacy berpengamb signifikan terhadap nilai pemsahaan. Berdasarkan hasil statistik menunjukkan signifikansi 0,028 yang artinya .financial literacy berhasil memoderasi stmktur modal sehingga berpengaruh signifikan terhadap nilai pemsallaan.

2. H2 rnenyatakan bahwa kebijakan dividen berpengaruh signifikan terhadap nilai perusahaan. Berdasarkan basil statistik rnenW1jukkan signifikansi 0,93 yang artinya kebijakan dividen tidak berpengaruh terhadap nilai perusahaan.

H2a rnenyatakan bahwa kebijakan dividen yang dirnoderasi oleh financial literacy berpengaruh signifikan terhadap nilai perusahaan. Berdasarkan hasil statistik menW1jukkan signifikansi 0,75 yang artinya financial literacy tidak mampu mernoderasi kebijakan dividen berpengaruh signifikan terhadap nilai perusahaan.

3. H3 rnenyatakan bahwa profitabilitas berpengaruh terhadap nilai perusahaan. Berdasarkan basil statistik rnenunjukkan signifikansi 0,05 yang artinya profitabilitas berpengaruh signifikan terhadap nilai perusahaan.

H3a menyatakan bahwa profitabilitas yang dimoderasi oleh financial literacy berpengaruh signifikan terhadap nilai pemsahaan. Berdasarkan basil statistik menW1jukkan signifikansi 0,35 yang artinya financial literacy tidak rnampu memoderasi profitabilitas terhadap nilai perusahaan.

Tabel 6. Uji Hipotesis (MRA) Perusahaan LQ45 Periode 2012 - 2016

\begin{tabular}{llccccc}
\multicolumn{1}{c}{ Model } & \multicolumn{2}{c}{ Unstandardized coefficients } & $\begin{array}{c}\text { Standardized } \\
\text { Coefficients } \\
\text { Beta }\end{array}$ & $t$ & Sig. \\
& (Constant) & $-31,413$ & 11,904 & & $-2,639$ &, 011 \\
& DER & 30,030 & 8,752 & 1,311 & 3,431 &, 001 \\
& DPR &,- 011 &, 132 &,- 019 &,- 085 &, 933 \\
ROA & 1,216 &, 611 & 1,132 & 1,991 &, 052 \\
& FL & 1,296 &, 794 &, 564 & 1,632 &, 109 \\
& DER*FL & $-1,298$ &, 571 &,- 912 & $-2,273$ &, 028 \\
& DPR*FL &, 002 &, 007 &, 073 &, 327 &, 745 \\
& ROA*FL &,- 041 &, 043 &,- 602 &,- 951 &, 347
\end{tabular}

a. Dependent Variable: PBV

Tabel 7. Hasil Pengujian Koefisien Determinasi

\begin{tabular}{|c|r|r|r|r|c|}
\hline Model & $\mathbf{R}$ & R Square & $\begin{array}{c}\text { Adjusted } \mathbf{R} \\
\text { SQuare }\end{array}$ & $\begin{array}{r}\text { Std. Error of } \\
\text { theEstimate }\end{array}$ & Durbin-Watson \\
\hline 1 &, $930 \mathrm{a}$ & $\mathbf{, 8 6 5}$ & $\mathbf{, 8 4 5}$ & $\mathbf{4 , 8 2 2 4 0}$ & 1,734 \\
\hline
\end{tabular}

a. Predictors: (Constant), ROA*FL, DER, DPR*FL, Fl, DPR, DER*Fl, ROA

b. Dependent Variable: PBV

Berdasarkan basil pengolahan SPSS, $\mathrm{R}$ Square 0,846 yang artinya 84,6\% variabel dependen yaitu nilai perusahaan (PBV) dipengaruhi variabel-variabel independen yakni struktur modal (DER), kebijakan dividen(DPR), dan profitabilitas (ROA). Dan 15,4\% dipengaruhi oleb faktor lainnya.

Pengujian Hipotesis

Berdasarkan uji bipotesis menggunakan MRA, hipotesis 1, 1a, dan 3 diterima. Sementara hipotesis 2, 2a, dan 3a ditolak. Hal ini dikarenakan siginifikansi untuk hipotesis 2, 2a, dan 3a $>5 \%$ dan $t$ hitung $<\mathrm{t}$ tabel. Berikut basil pengujian hipotesis yang diajukan :

1. $\mathrm{H}_{1}$ menyatakan bahwa struktur modal berpengaruh signifikan terhadap nilai perusallaan.

Berdasarkan basil statistik menunjukkan signifikansi 0,001 yang artinya struktur modal 
berpengamh signifikan terhadap nilai pemsallaan. Dengan demikian H1 terbukti atau dapat diterima.

H1a menyatakan ballwa struktur modal yang dimoderasi olehfinancial literacy berpengaruh signifikan terhadap nilai perusallaan. Berdasarkan basil statistik menunjukkan signifikansi 0,028 yang artinya financial literacy berhasil memoderasi strul1:ur modal sehingga berpengaruh signifikan terbadap nilai perusahaan. Dengan Demikian $\mathrm{H}$ 1a terbukti atau dapat diterima.

2. H2 menyatakan ballwa kebijakan dividen berpengaruh signifikan terbadap nilai perusahaan. Berdasarkan basil statistik menunjukkan signifikansi 0,93 yang artinya kebijakan dividen tidak berpengaruh terhadap nilai perusahaan. Dengan demikian H2 tidak terbukti atau ditolak.

H2a menyatakan bahwa kebijakan dividen yang dimoderasi oleh financial literacy berpengaruh signifikan terhadap nilai pemsahaan. Berdasarkan hasil statistik menunjukkan signifikansi 0,75 yang artinya financial literacy tidak mampu memoderasi kebijakan dividen berpengaruh signifikan terhadap nilai pemsahaan . Dengan demikian H2a tidak terbukti atau ditolak.

3. H3 menyatakan bahwa profitabilitas berpengaruh terhadap nilai pemsahaan. Berdasarkan basil statistik menunjukkan signifikansi 0,05 yang artinya profitabilitas berpengaruh signifikan terhadap nilai pemsahaan. Dengan demikian H3 terbukti atau dapat diterima. H3a menyatakan bahwa profitabilitas yang dimoderasi oleh financial literacy berpengaruh signifikan terhadap nilai perusahaan. Berdasarkan basil statistik menunjukkan signifikansi 0,35 yang artinya .financial literacy tidak mampu memoderasi profitabilitas terhadap nilai perusahaan. Dengan demikian HJa tidak terbukti atau ditolak.

\section{Pembahasan}

Dari basil pengujian hipotesis pertama diketahui bahwa H1 : struktur modal berpengaruh signifikan terhadap nilai pemsahaan dan $\mathrm{H1a}$ : struktur modal yang dimoderasi oleh financial literacy berpengaruh signifikan terhadap nilai perusahaan. Hasil penelitian ini sesuai dengan penelitian yang dilakukan oleh Ni Luh Putu Gayatri dan I Ketut Mustanda (2014) dan Ayu Sri dan Ary Wirajaya (2013), menyimpulkan bahwa struktur modal berpengaruh signifikan terhadap nilai perusahaan dan financial literacy mampu memoderasi pengaruh struktur modal yang signifikan terhadap nilai perusahaan. Melalui struktur modal yang dikelola manajemen dengan baik dan benar, perusahaan mampu mengoptimalkan nilai perusahaan. Hal ini terjadi apabila perusahaan mampu memadupadankan komposisi modal perusahaan sehingga menghasilkan kemakmuran bagi para pemegang saham. Keberhasilan pihak manajemen perusaliaan dalam memakmurkan para pemegang saham dipicu oleh tata kelola manajemen dalam memadupadankan komposisi modal yang dimiliki oleh perusahaan tersebut. Pendapat sendiri didukung dengan data DER.

Hasil penelitian ini tidak sesuai dengan penelitian yang dilakukan oleh Ta'dir Eko Prasetio dkk (2014) yang menyatakan ballwa struktur modal tidak signifikan berpengaruh terhadap nilai perusahaan. Hal ini disebabkan oleh alat pengukuran yang digunakan dalam penelitian berbeda yakni dalam penelitian ini nilai perusahaan menggunakan Price to Book Value, sedangkan dalam penelitian Ta'dir Eko Prasetio (2014) menggunakan turbin Q. Selain itu sampel populasi yang digunakan berbeda, di dalam penelitian ini menggunakan data perusahaan LQ45 periode 2012-2015, tidak menggunakan data perusahaan manufaktur yang terdaftar di BEI periode 2008-2012. Banyak alat ukur yang dapat digunakan tmtuk menggambarkan variabel struktur modal namun yang lazim digunakan adalah DER. Sementara untuk variabel nilai perusahaan terdapat dua pendekatan yakni pendekatan melalui harga saham dan melalui pendekatan intrinsik (menggunakan rasio Price to Book Value). Harga saham yang bisa digunakan untuk mengukur nilai perusahaan adalah harga pembuka dan harga saat penutupan.

Dari hasil pengujian hipotesis kedua diperoleh bahwa H2 : kebijakan dividen tidak
Firm Value,
Capital Structure
and Profitability

273 
Firm Value, Capital Structure and Profitability

274 berpengaruh terhadap nilai perusahaan dan $\mathrm{H} 2 \mathrm{a}$ : kebijakan dividen yang dimoderasi oleh financial literacy tidak berengaruh terhadap nilai perusahaan. Hasil penelitian ini sesuai dengan penelitian yang dilakukan oleh Umi dkk (2012) menyimpulkan bahwa kebijakan dividen tidak berpengaruh terhadap nilai perusahaan. Kenapa tidak berpengaruh dijelaskan Kebijakan dividen hanya sebuah cara yang dapat digunakan oleh perusahaan untuk mengkomunikasikan signal untuk para investor maupun calon investor agar tertarik menanamkan modal di pemsahaan. Kemampuan dalam mengelola keuangan di suatu perusahaan terkadang tidak memberikan signal positif untuk para investor. Kemampuan mengelola keuangan perusahaan salah satunya dengan kebijakan dividen diharapkan perusahaan dapat meningkatkan nilai perusahaan.

Dari basil pengujian hipotesis ketiga diperoleh bahwa H3 : profitabilitas berpengaruh signifikan terhadap nilai perusahaan dan $\mathrm{H3a}$ : profitabilitas yang dimoderasi oleh financial literacy tidak berpengaruh terhadap nilai perusahaan. Hasil penelitian ini sesuai dengan penelitian yang dilakukan oleh Titin Herawati (2013), menyimpulkan bahwa profitabilitas berpengaruh signifikan terhadap nilai pemsahaan dan Nur' Aini dkk (2013), menyimpulkan bahwa profitabilitas yang dimoderasi olehjinandal literacy tidak berpengaruh terhadap nilai perusahaan. Kemampuan perusahaan dalam menciptakan laba perusahaan akan menarik minat para penanam modal untuk berinvestasi di perusallaan tersebut. Semakin besar keuntungan yang dapat dihasilkan maka semakin besar peluang para pemegang saham itu makmur oleh perusahaan. Kemampuan mengelola keuangan dalam suatu perusahaan tidak selalu membuahkan basil dalam jangka waktu dekat, butuh proses dalam menuai hasil dari sebuah pekerjaan. Penjualan di akhir periode pelaporan akan masuk ke dalam penjualan periode selanjutnya. Hasil penelitian ini tidak sesuai dengan penelitian yang dilakukan oleh lka Fanindya (2013) menyimpulkan bahwa profitabilitas tidak signifikan berpengaruh terhadap nilai perusahaan. Hal ini disebabkan oleh perbedaan alat ukur yang digunakan untuk memproksikan variabel tersebut dan periode pengamatan yang berbeda. Dalam penelitian ini ROA digunakan untuk mengukur profitabilitas sedangkan lka Fanindya (2013) menggunakan ROE untuk mengukur profitabilitas. Peri.ode pengamatan yang dilakukan lka Fanindya (2013) berbeda selisih empat talmn dengan periode pengamatan yang penulis lakukan.

\section{PENUTUP}

Dari hasil penelitian ini maka dapat disusun kesimpulan sebagai berikut :

1. Struktur modal berpengaruh terhadap nilai perusahaan. Semakin baik struktur modal perusahaan maka semakin tinggi nilai perusahaannya. Struktur modal berpengaruh terhadap nilai perusahaan yang dimoderasi oleh financial literacy. Financial literacy akan memperkuat pengaruh struktur modal terhadap nilai perusahaan. Hasil penelitian ini sesuai dengan penelitian yang dilakukan oleh Ni Luh Puhl Gayatri dan I Ketut Mustanda (2014) dan Ayu Sri dan Ary Wirajaya (2013), menyimpulkan bahwa struktur modal berpengaruh signifikan terhadap nilai perusallaan dan financial literacy mampu memoderasi pengaruh struktur modal yang signifikan terhadap nilai perusallaan. Dengan demikian hipotesis 1 dan 1a diterima.

2. Kebijakan dividen tidak berpengaruh terhadap nilai pemsahaan. Kebijakan dividen yang dimoderasi oleh financial literacy juga tidak berpengaruh terhadap nilai pemsahaan. Hasil penelitian ini sesuai dengan penelitian yang dilakukan oleh Umi dkk (2012) menyimpulkan bahwa kebijakan dividen tidak berpengaruh terhadap nilai perusahaan. Dengan demikian hipotesis 2 dan 2 a ditolak.

3. Profitabilitas berpengaruh signifikan terhadap nilai pemsahaan tetapi financial literacy tidak terbukti memoderasi pengaruh profitabilitas terhadap nilai perusahaan. Semakin tinggi profitabilitas maka semakin tinggi nilai perusahaan, akan tetapi financial literacy memperlemah pengaruh kebijakan dividen terhadap nilai perusahaan. Hasil penelitian ini 
sesuai dengan penelitian yang dilakukan oleh Titin Herawati (2013), menyimpulkan bahwa profitabilitas berpengaruh signifikan terhadap nilai perusahaan dan Nur'Aini dkk (2013), menyimpulkan bahwa profitabilitas yang dimoderasi oleh finandal literacy tidak berpengaruh terhadap nilai perusahaan. Dengan demikian hipotesis 3 diterima dan hipotesis 3 a ditolak.

\section{DAFTAR PUSTAKA}

Akbar, B., Aziz, H.A., Djazuli, A., Kowi, M. and Amyar, F., 2018, February. Performance Effectiveness Measurement of Village Funding Management Using Fuzzy Inference System (FIS) Method. In Conference Proceedings Jakarta Indonesia, ICABE 2018.

Anwar, A.D. and Amyar, F., 2020. Analisis Faktor-Faktor Yang Mempengaruhi Kualitas Audit Internal Dalam Pengambilan Keputusan Laporan Keuangan Pada PT Damar Bandha Jaya Bogor. Jurnal Ilmiah Akuntansi Kesatuan, 8(1), pp.87-96.

Damayanti, E. W., dan Fitriyah, Fitriyah. 2012. Pengaruh Corporate Governance Dan Rasio Akuntansi Terhadap Peringkat Obligasi. Iqtishoduna.

Dewi,Ayu Sri Mahatma dan Ary Wirajaya . 2013 ." Pengaruh Struktur Modal, Profitabilitas dan Ukuran Perusahaan terhadap Nilai Perusahaan". E-Journal Akuntansi Universitas Yudayana, 358-372.

Emmy, S., Purba, J.H.V. and Rangga, M., 2006. Pengaruh endoser pada media iklan televise terhadap citra produk. Journal Ekonomi dan Bisnis, 6(2), pp.99-103.

Fauzi, R.C., Patriani, Y., Tiblola, J. and Munawar, A., 2020. Neo-Nepotism In Business Which Reducesthe Quality Of Democracy. European Journal of Molecular \& Clinical Medicine, 7(11), pp.1758-1763.

Fitria, A. and Munawar, A., 2021. Pengaruh Penggunaan Internet Banking, Mobile Banking Dan SMS Banking Terhadap Kepuasan Nasabah Bank BNI. Jurnal Informatika Kesatuan, 1(1), pp.41-50.

Ghozali, I. 2013. "Aplikasi Analisis Multivariate dengan Program IBM SPSS", ed 21, Cetakan VII. UNDIP. Semarang

Herawati, Titin. 2013. "Pengaruh Kebijakan Dividen, Kebijakan Hutang dan Profitabilitas Terhadap Nilai Perusahaan". Jurnal Manajemen, 2.02.

Hermuningsih,Sri.2013. " Pengaruh Profitabilitas,Growth Opportunity,Struktur Modal terhadap Nilai Perusahaan pada Perusahaan Publik Indonesia". Buletin Ekonomi Moneter dan Perbankan,Edisi Oktober 2013.

Hikmah Endraswati. 2009. Pengaruh Struktur Kepemilikan Dan Kebijakan Deviden Terhadap Nilai Perusahaan Dengan Kebijakan Hutang Sebagai Variabel Moderating Pada Perusahaan Di BEI. Skripsi. STAIN Salatiga.

Jusriani, Ika Fanindya. 2013. Analisis Pengaruh Profitabilitas, Kebijakan Dividen, Kebijakan Utang, dan Kepemilikan Manajerial Terhadap Nilai Perusahaan. Semarang: Universitas Diponegoro.

Kusumajaya,Dewa Kadek Oka. 2011. "Pengaruh Struktur Modal dan Pertumbuhan Perusahaan terhadap Profitabilitas dan Nilai Perusahaan pada Perusahaan Manufaktur di Bursa Efek Indonesia. Tesis, Denpasar : Universitas Udayana.

Mardiati,Umi,dkk.2012." Pengaruh Kebijakan Deviden,Kebijakan Utang dan Profitabilitas Tterhadap Nilai Perusahaan Manufaktur yang Terdaftar di Bursa Efek Indonesia". Jurnal Riset Manajemen Sains, Vol. 3 No. 1.

Munawar, A., Duwila, U. and Harini, D., 2020. A Review on Types of Money in the Development of Community Trade. Journal of Critical Reviews, 7(8), pp.1993-1997.

Munawar, A. and Marpaung, B.S., 2013. Pengaruh Arus Kas Operasi Terhadap Peningkatan Kemampulabaan dan Pertumbuhan Perusahaan STUDI KASUS PADA PT. HOLCIM INDONESIA, TBK. Jurnal Ilmiah Manajemen Kesatuan, 1(3), pp.213-217.

Neva, S. and Amyar, F., 2021. Pengaruh Fraud Diamond dan Gonetheory Terhadap
Firm Value, Capital Structure and Profitability 
Firm Value, Capital Structure and Profitability
Academic Fraud. JAS-PT (Jurnal Analisis Sistem Pendidikan Tinggi Indonesia), 5(1), pp.29-38.

Prasetyorini, Bhekti Fitri. (2013). "Pengaruh ukuran perusahaan, leverage, price earning ratio dan profitabilitas terhadap nilai perusahaan". Jurnal Ilmu Manajemen. 1.1: 183-196.

Purba, J.H.V., 2001. Keragaan Kelapa Sawit Indonesia Ditinjau dari Jenis Pengusahaan dan Wilayah Produksi.

Putra, I wayan Juniastina dan Ni Luh Putu Wiagustini. 2014. "Pengaruh Leverage dan Profitabilitas terhadap Kebijakan Deviden dan Nilai Perusahaan” Hal.2668- 2684.

Remund, David L. (2010). Financial Literacy Explicated: The Case for a Clearer Definition in an Increasingly Complex Economy. The Journal of Consumer Affairs, 44 (2), 276295. Diunduh pada tanggal 19/10/ 13:26 WIB.

Sofyaningsih, Sri Pacawati Hardiningsih (2011). Struktur Kepemilikan, Kebijakan Dividen, Kebijakan Utang Dan Nilai Perusahaan Ownership Structure, Dividend Policy And Debt Polcy And Firm Value. Dinamika Keuangan Dan Perbankan Vol. 3, No. 1.

Ta'dir Eko,dkk.2014. " Struktur Modal,Ukuran Perusahaan dan Resiko Perusahaan terhadap Nilai Perusahaan Otomotif yang Terdaftar di BEI".Jurnal EMBA, Edisi Juni 2014,Vol.2 No.2 Hal. 879-889.

Widyawati. (2012). "Faktor-faktor yang Mempengaruhi Literasi Finansial Mahasiswa Fakultas Ekonomi dan Bisnis Universitas Brawijaya". Jurnal Akuntansi dan Pendidikan Vol. 1. No. 1. Diakses pada 28 Mei 2018 